\title{
Free blood donation vs. the plasma market
}

Blood products are vital both for transfusion purposes and derived medicines. Currently the two ways of obtaining blood products are via free international plasma market an industry reliant on paid Jean Mercier Ythier of the University of Paris PanthéonAssas explores the economics and ethics of the plasma market and suggests possible sufficient supplies of this allimportant resource. blood donations or via the long-term solutions for

cood is made up of several main aining haemoglobin, to carry oxygen around the body), white blood cells (to destroy bacteria and viruses), platelets (to help blood to clot) and plasma (the liquid portion of the blood suspending the blood cells, which Whilst free donations remain the norm blood products an international market reliant on paid-for donations exists for plasma and its derivatives. Remunerated donations have received ethical criticism in the past, due to concerns with donor being more vulnerable people and an increased risk of disease transmission.

\section{THE PLASMA MARKET}

Blood donation is unique in transplant medicine, in that established collection organisations can provide blood products sufficient in quality and quantity to meet

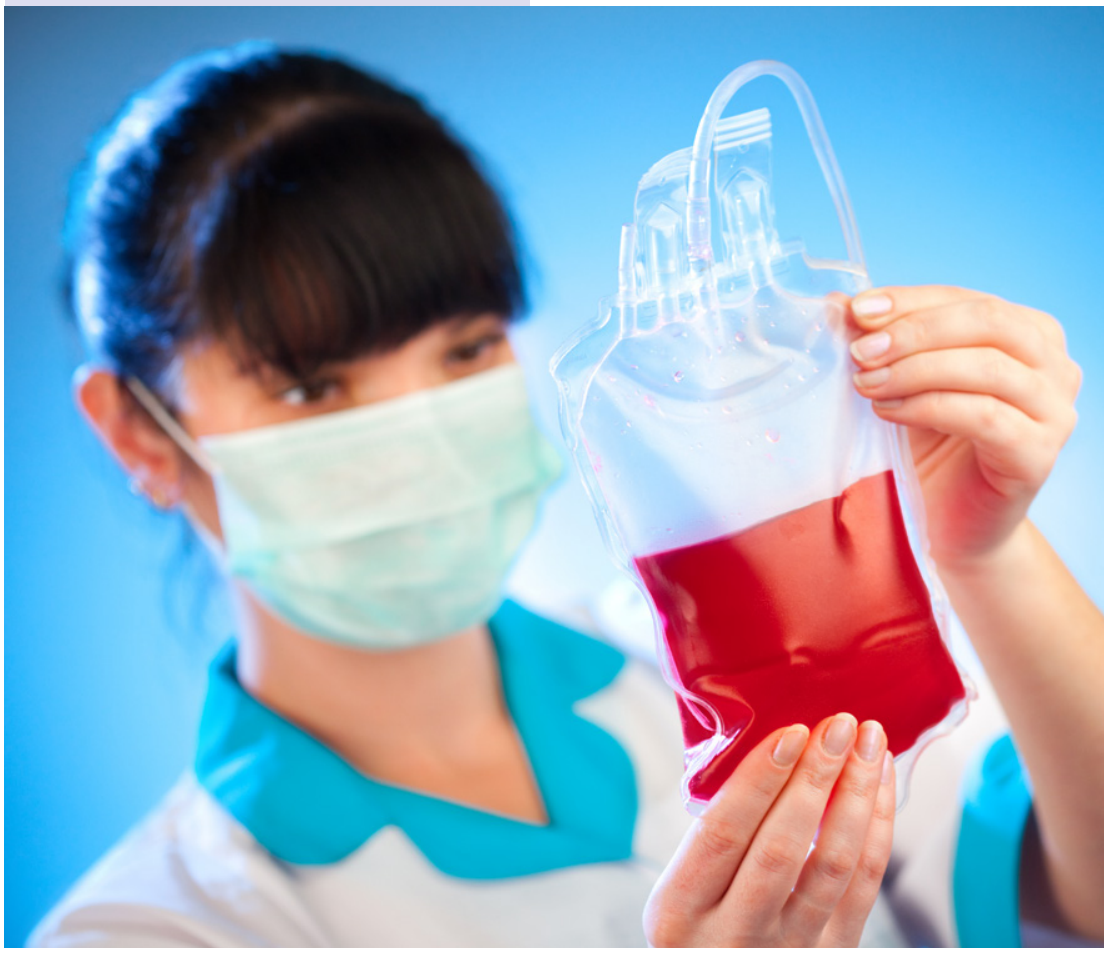

demand, contrasting greatly with kidney, Iver, lung and hear transplants. Plasma, specifically, is the only part of the human body that is marketed on a global scale. The plasma maket coexists with plasma

The process of separating a substance into its individual components is know n. Blood fractionation the 'buffy coat' (contining white cels, cells and platelets), and plasma Plasma can then in turn undergo fractionation to produce various individual proteins. Arguably the most important of these are immunoglobulins (immune proteins whic destroy bacteria and viruses), which are vital in the treatment of immunodeficiency diseases. Blood-derived medicines such as immunoglobulins are typically produced by large for-profit companies, which has resulted in a massive increase in demand for plasma over recent decades. This has created an plasma, which is fed almost exclusively by exported plasma from the USA. Plasmapheresis is the process by which The vast majority of exported plasma from the USA (which acts as the main raw material for companies to produce plasma-derived medicines) is sourced from remunerated plasmapheresis. The Plasma Protein Therapeutics Association (PPTA) reported a rapid growth in collection of fractionation plasma over the past decade, by approximately $25 \%$ per year. The number of plasmapheresis centres in the USA doubled over the same time period. In 2014, the USA supplied over $70 \%$ of world demand of fractionation plasma, which was predominantly obtained via paid plas donations. A large proportion of this

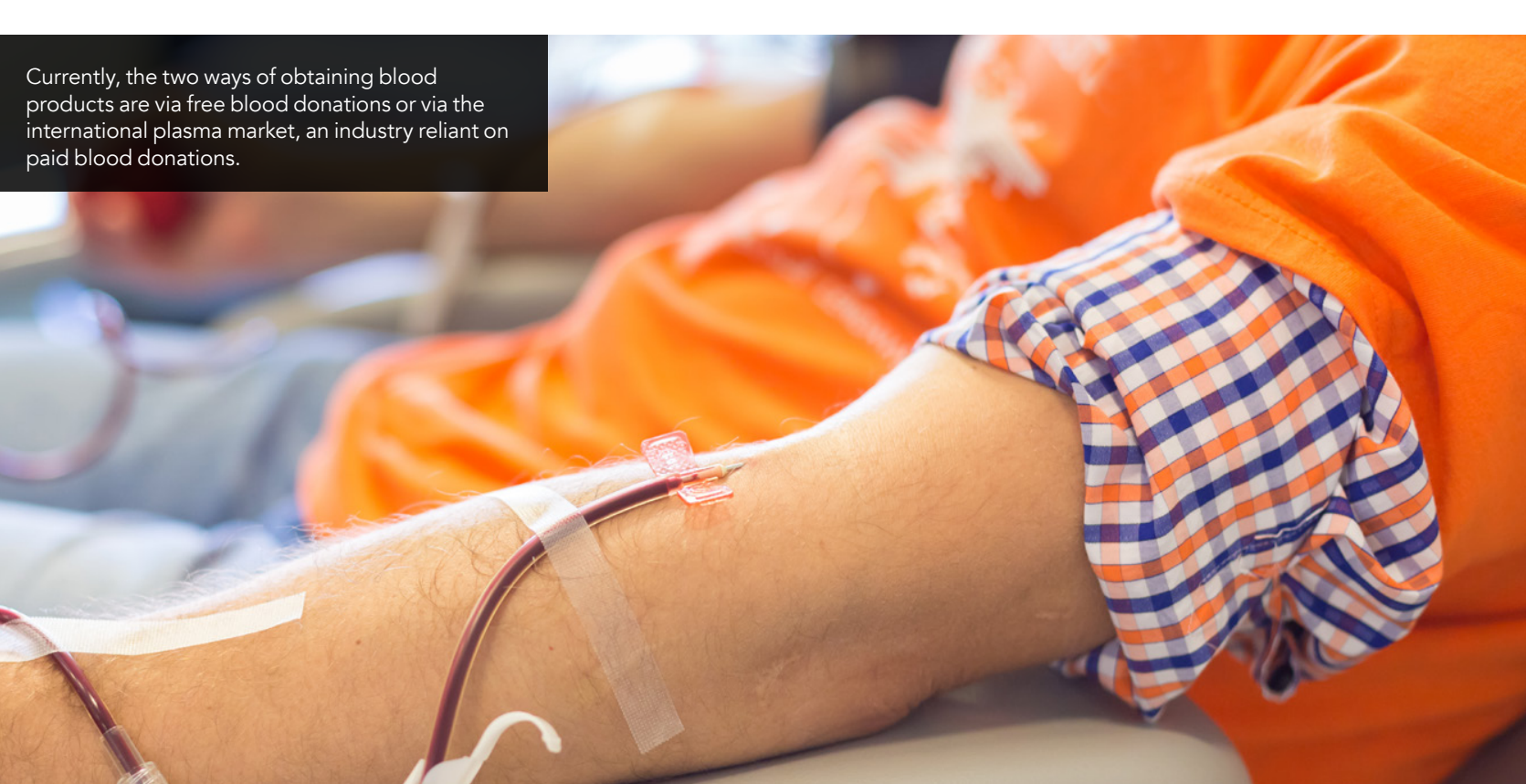

The international plasma market has been described as a 'contested market".

The hourly compensation for a plasmapheresis session equates to slightly higher than the USA average wage. If the compensation exceeds the value of the time spent on the donation (calculated from minimum hourly wages of standard job markets), then the donation should be classed as a sale. This is the case in the USA and, on a smaller scale, Germany.

The international plasma market has been described as a 'contested market', namely due to previous ethical criticism of remunerated blood donations, and statistical inconsistencies in the reporting of plasma donations, where data Organization seem to differ

Collected plasma (as with any blood product) is invoiced at each step up to the end consumer. Depending on the environment, the cost of the plasma may be an administered, regulated or market price. The main two factors in the determination of this sale price are production cost (cost of collection storage and transportation), and leve of demand.

ETHICAL ISSUES

The three main historic arguments against the plasma market are: a 'crowding may cause a reduction in free blood dontested market. potential donors are more likely to hide the risk of transmissible diseases; and the issue of fairness, as paid donors are more likely to be vulnerable (affected by poverty, discrimination or drug addiction) However, with the development of globalisation and improved safety measures, he second one of these cricisms becomes less weighty. The other important factor to consider is ensuring the high demand of plasm is met, to allow ongoing production

has been hypothesised that offering would crowd out the donations individuals' motives. This effect has not been proven, whereas a positive effect on overall supply has; monetary supply of plasma. Similar conclusions can be reached from data from both the USA and Germany. Furthermore, in Germany, monetary incentive increased total supply by increasing both the number of donors and the number of donations per donor per year. It should be noted that in the case of the USA, an increase in total supply is likely not to but a so an increase in total number of plasmapheresis centres.

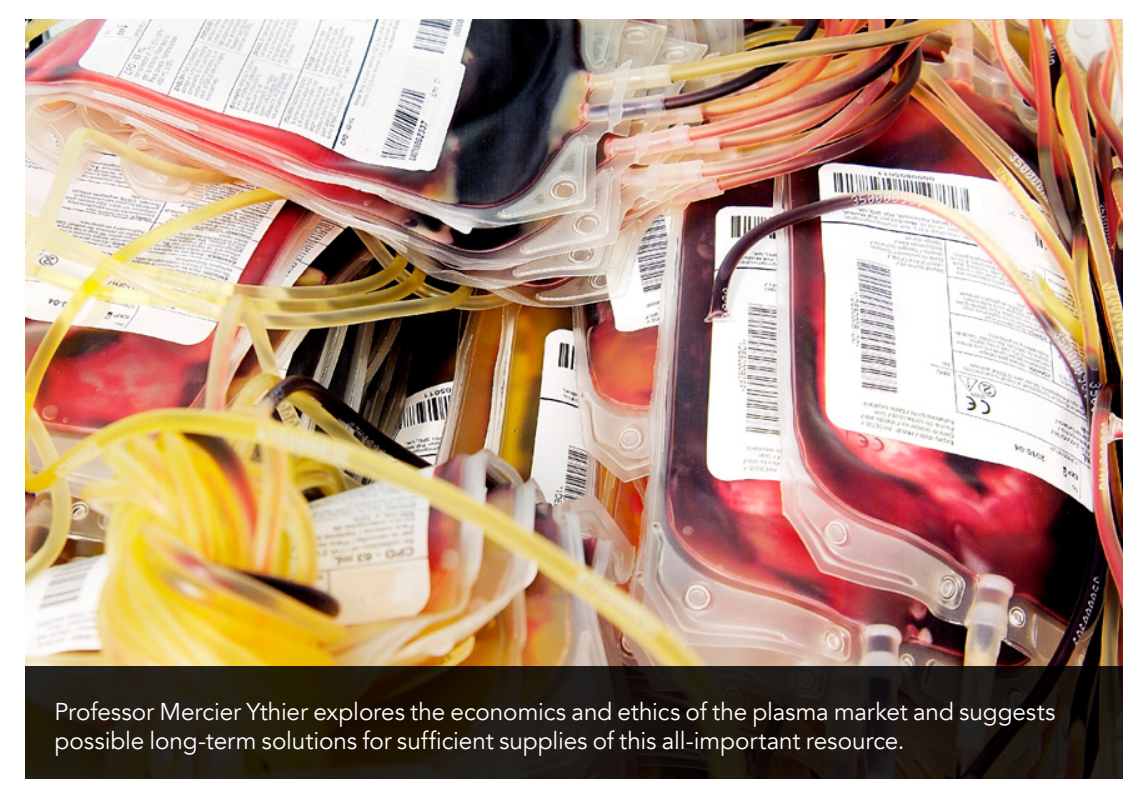
incentive therefore increases the total 
Safety of blood products is highly important, and h has previously been incentive for donation will have a negative incidence on safety, namely by increased disease transmission. However blood donation relies on a number of processes such as screening, pathogen inactivation and haemovigilance. Unpaid donation alone is not a safety control measure; in fact, no difference has been proven between paid and unpaid donations in terms of safety when these good practices are implemented. Subject to the latter condition, monetary compensation for donation therefore increases quantity without compromising on quality. It can be argued that in the absence of large supples of paid-for donated plasma from the USA, the wolldwide demand ay not be met. The collection cost of combined paid and unpaid donations.

The two modes of blood donation can be categorised into the common resource from free blood donations, which is distributed by transfusion organisation and the industrial raw material from marketed globally. Professor Jean Mercier Ythier offers the following possible solutions to the tension between these two contrasting states.

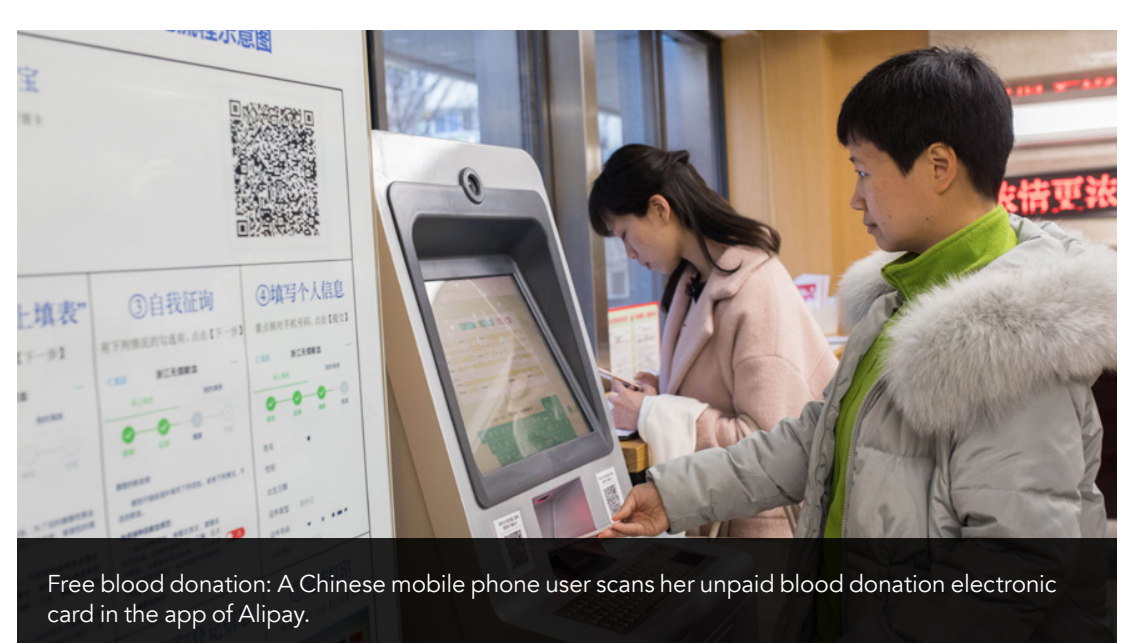

CONTRACT FRACTIONATION One such solution would be the development of fractionation contracts, between the collection organisation (usually a nonpoft orgaisation) and public or non-prefitcompany) The sale price would be regulated by the government This model would be in the interest of national self-sufficiency (which is recommended by the WHO) by allowing national states to ensure their citizens have access to blood products sufficient in quality and quantity Development of the aforementioned contracts would allow for diversification in the sources of the plasma supply to the fractionators, reducing the risk of

Innovations in the field of blood products could reduce or eradicate reliance on blood donations altogether.

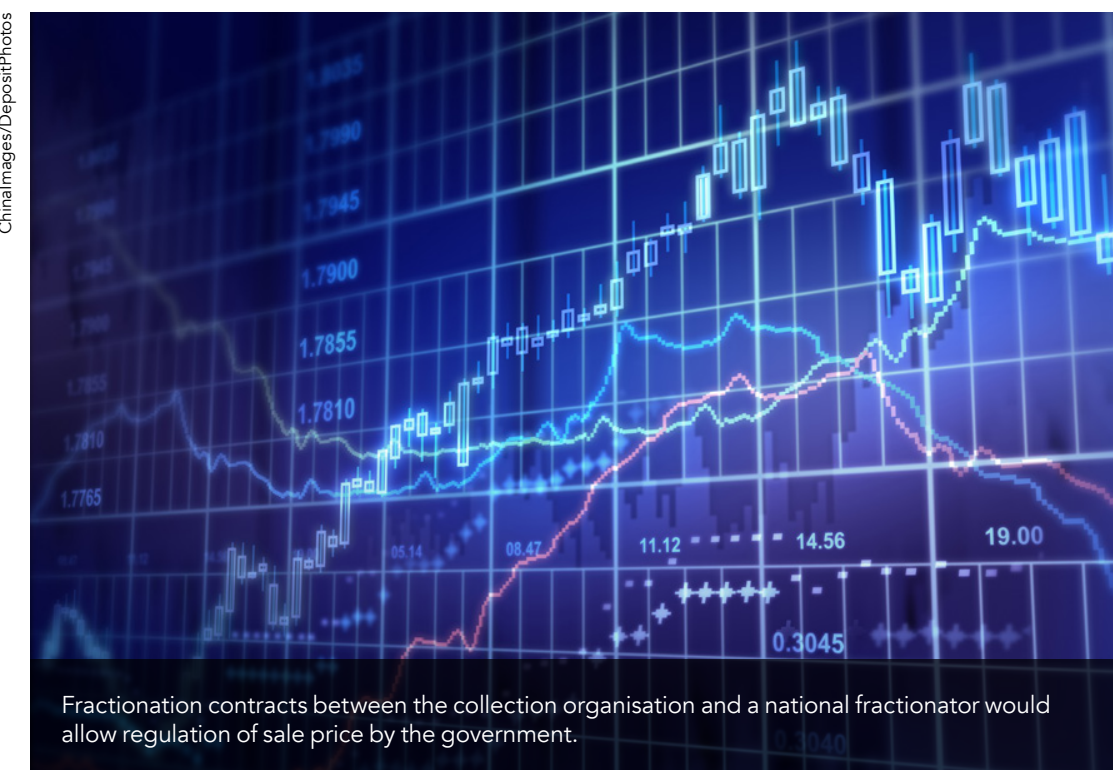

interruption to said supply. This method would lead to an increased supply of non-remunerated plasmapheresis with the support of contracts that would set sale prices high enough to cover costs even

\section{SCIENTIFIC INNOVATION}

Innovations in the field of blood products could reduce or even, in some cases, eradicate reliance on blood donations use of genetic engineering in producing coagulation factors (proteins in the blood that help to control bleeding). In the 1970 and 1980 s, coagulation factors were a ind led to significant clinical progress in the management of haemophilia (a disease which affects the ability of the blood to clot). The introduction of genetically engineered coagulation factors has meant that the treatment of haemophilia is no longer reliant on fractionation. It case in high-income countries where genetic engineering can be utilised, and coagulation factors from human plasme to the genetically engineered alternative.

The second example is the development of techniques for the mass-production of blood cells from haematopoietic stem cells (cells which can develop into different blood cells). If this was possible, blood cell blood donations. However, the research and development of such techniques are in the early stages and are not guaranteed. Biomedical advances such as these would allow the demand of blood products to be met without depleting altogether. One example of this is the in some cases, clinicians prefer the une of transfusion would no longer be reliant on

\section{Behind the Research}

\section{Professor Jean Mercier Ythier}

E: jean.mercier-ythier@u-paris2.f

W: https://www.linkedin.com/in/jean-mercier-ythier-3bb48674/?originalSubdomain=fr

\section{Research Objectives}

Professor J. Mercier Ythier's research interests include the theory of general competitive equilibrium, wealth distribution, public economic theory, economic philosophy, political economy, altruism, ethics, and topics of economic anthropology.

\section{Detail}

Jean Mercier Ythier

Université de Paris Panthéon-Assas

12 place du Panthéon

France Paris

France

Bio

Wrief the University of Paris Panthéon-Assas, France since 2010. Prior to this, he was Professor of economics at University of Lorraine.

Funding

University of Paris Panthéon-Assas

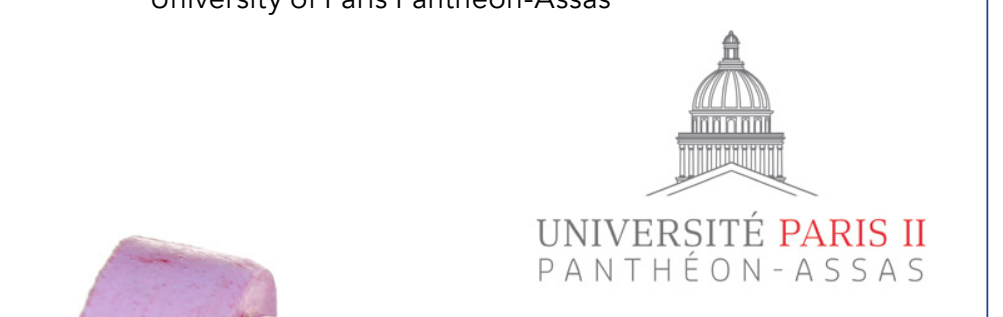

\section{References}

Mercier Ythier, J. (2020) The contested market of plasma. Transtusion Clinique et Biologique 27: 52-57. doi: 10.1016/j.tracli.2019.10.003

Mercier Ythier, J. (2020) Some considerations on the longterm prospects of plasma markets. Jounnal of Tr.

Mercier Ythier, J. (2017) Who owns haematopoietic stem cells? Some fundamental legal stakes for the manufacture of cultured red blood cells. Journal of Transplant Surgery 1 (1): 1-7. doi: 10.36959/338/324

\section{Personal Response}

What are your predictions for the plasma market over

II The demand for fractionation plasma will presumably pursur. We shound also obs immunoglobulins diversification in the origins of fractionation plas diversification in the origins of fractionation plasma,
with, on the one hand, an increased provision of paid plasmapheresis by a number of emerging industrial countries, and, on the other hand, an increased provision of non-remunerated plasmapheresis by a support free blood dontion. This colld possibly resut in a decrease, or in a stabilisation of the share of paid plasmapheresis in the consumption of some countries Western Europe for instance.

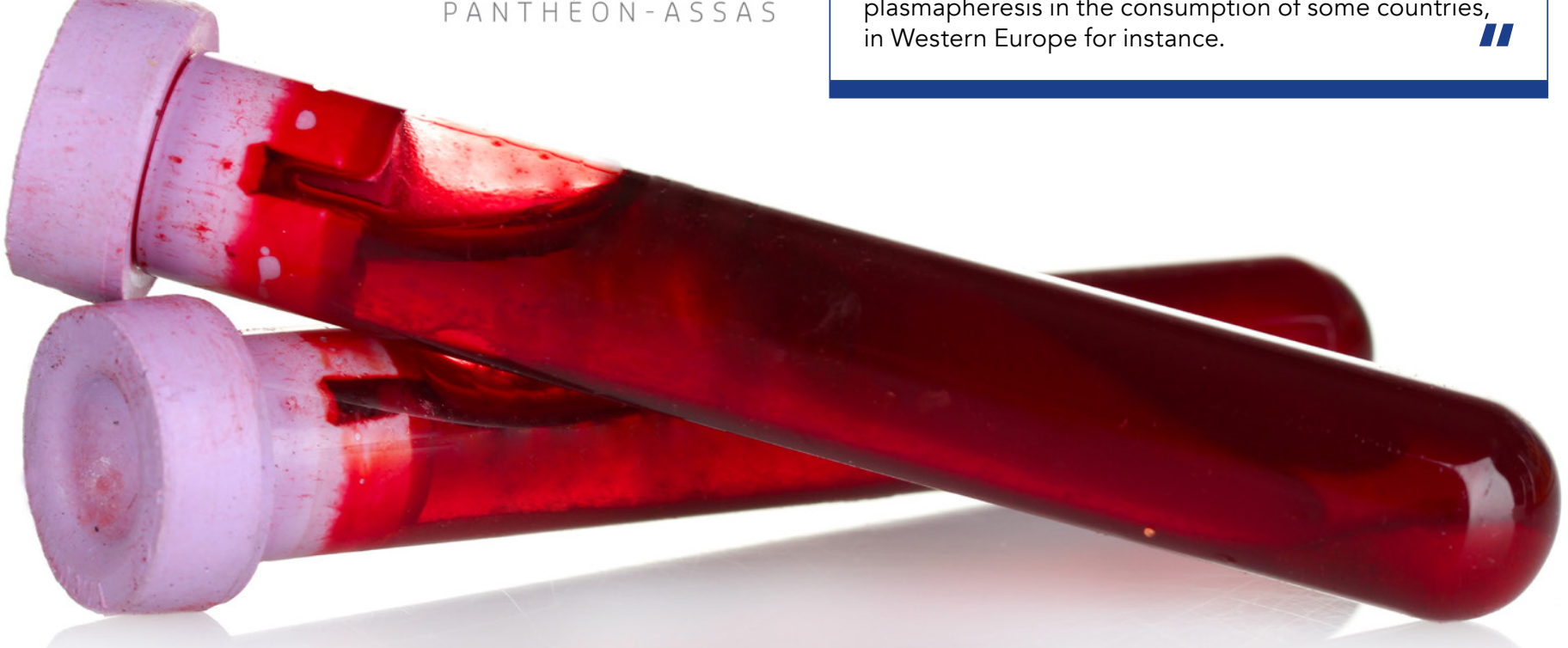

